Cite this: J. Mater. Chem. A, 2013, 1, 15397

Received 10th September 2013 Accepted 10th October 2013

DOI: $10.1039 / c 3 \operatorname{ta} 13621 c$

www.rsc.org/MaterialsA

\section{Sol-gel synthesis and impedance characteristics of networked nanocrystalline olivine cathode for Li-ion full cells}

\author{
P. Manikandan, P. Periasamy and R. Jagannathan* \\ A sol-gel synthesis using adipic acid yielded small particles of around $20 \mathrm{~nm}$ in size of olivine $\mathrm{LiFePO}_{4} / \mathrm{C}$ \\ cathode materials. In the characterization of cathode system(s), solid state impedance spectra of the \\ pristine $\mathrm{LiFePO}_{4} / \mathrm{C}$ cathode revealed clear localization of charge through charge build-up. \\ When networked with MWCNT, this material facilitates enhancement in charge mobility, eventually \\ explaining the capacity enhancement of the $\mathrm{LiFePO}_{4} / \mathrm{C}-\mathrm{MWCNT}$ electrode, which yields a high capacity \\ of $163 \mathrm{~mA} \mathrm{~h} \mathrm{~g}^{-1}$ at $\mathrm{C} / 10$. On the other hand, the lower capacity of $125 \mathrm{~mA} \mathrm{~h} \mathrm{~g}^{-1}$ found for the pristine \\ $\mathrm{LiFePO}_{4} / \mathrm{C}$ electrode material can be explained in terms of charge becoming localized/trapped in the \\ vicinity of inter- and intra-granular regions of the cathode particles. To get a broader view of the \\ application potential (in terms of cell voltages of $\sim 3 \mathrm{~V}, 2 \mathrm{~V}$, and safety aspects) of the networked \\ cathode materials, two kinds of $\mathrm{Li}$-ion full cells using mesocarbon microbeads (MCMB) and $\mathrm{Li}_{4} \mathrm{Ti}_{5} \mathrm{O}_{12}$ as \\ anodes were fabricated, which yielded capacities of 1.94 and $2.1 \mathrm{~mA}$ h respectively.
}

\section{Introduction}

Li-ion batteries used as energy sources for multifarious applications employ layered $\mathrm{LiCoO}_{2}, \mathrm{LiNi}_{1 / 3} \mathrm{Mn}_{1 / 3} \mathrm{Co}_{1 / 3} \mathrm{O}_{2}$ and also spinel $\mathrm{LiMn}_{2} \mathrm{O}_{4}$ oxide ceramics as cathode systems. However, a variety of cathode materials are currently being researched to address challenges related to flat cell voltage, cyclability, cost and toxicity issues. ${ }^{1}$ In this scenario, the olivine-type $\mathrm{LiFePO}_{4}$ system has an edge over other cathode systems owing to the occurrence of two inherently robust chemical phases that arise in covalent orthorhombic phosphate phases, namely $\mathrm{LiFePO}_{4}$ and $\mathrm{FePO}_{4}$, upon electrochemical cycling, and the propensity for chemical breakdown of the host constituents is very pronounced during electrochemical cycling. ${ }^{2}$ Furthermore, another challenge is the stability of the cathode(s) during the operation of batteries in arrays, leading to excessive heat generation. ${ }^{3}$ Because of its more stable three dimensional structure, the $\mathrm{LiFePO}_{4}$ system can endure both chemical breakdown upon cycling as well heat generation, which makes this system an ideal candidate as a prospective structurally stable cathode, with immense potential for applications. However, the dismal electronic ${ }^{4,5}$ and ionic conductivities ${ }^{6,7}$ of this olivine-type cathode system are the major limiting factors on the capacity of the electrochemical power system. These shortcomings can be overcome through surface coating, ${ }^{8,9}$ aliovalent doping ${ }^{10,11}$ and size miniaturization. ${ }^{12-14}$ In this

FMD and Lithium Batteries - Electrochemical Power Sources Division, Central Electrochemical Research Institute (CECRI - CSIR), Karaikudi 630 006, T. N., India. E-mail: jags57_99@yahoo.com; Fax: +91 4565227713; Tel: +91 9487167780 context, it is significant to highlight the insightful, exhaustive review centering on the different strategies adopted for the surface coating of $\mathrm{LiFePO}_{4}$ cathode systems, eventually aiming at great enhancement of the cathode performance. ${ }^{15}$ The miniaturization to the nanoscale of these particles is significant, as this can decrease the diffusion length of Li ions, facilitating efficient $\mathrm{Li}$ ion transportation ${ }^{16}$ in the cathode material. Although particle size reduction down to the nanoscale $(\sim 30 \mathrm{~nm})$ may enhance the transportation of $\mathrm{Li}$ ions, ${ }^{17}$ poor particle to particle contact eventually reduces the conductivity, ${ }^{18}$ which is a major consequence that needs to be addressed.

In order to address these issues, in this study we have attempted the synthesis of small olivine cathode materials $(\varnothing$ around $20 \mathrm{~nm})$ through a sol-gel route employing adipic acid, for the reason that the organic fuel might leave more residual carbon following thermolysis in addition to resulting in ultra fine nanoparticles. The unique feature of the present report is that here the average particle size is much smaller than in previous reports ${ }^{19}$ which yielded larger particles $(\sim 100 \mathrm{~nm})$, even though they used the same chelating agent. ${ }^{20,21}$ It has previously been reported that embedding pristine cathode particles in functionalized multi-walled carbon nanotubes

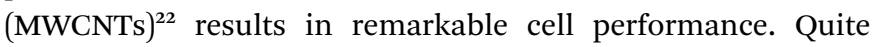
recently there has been extensive research demonstrating the importance of pure, doped CNTs when networked with olivine cathodes to achieve higher capacities..$^{23,24}$ The lithium battery community (using $\mathrm{LiFePO}_{4}$ cathodes) has attempted to achieve higher capacity and rate capability through networking with conducting carbon in several forms, including carbon fiber, 
graphene and MWCNTs, etc. However, in terms of electrical conductivity, surface area and aspect ratio, MWCNTs have clear advantages over other forms of conducting carbon. ${ }^{15,25,26}$ In view of these outstanding features, we have chosen MWCNTs as the networking medium for the synthesized cathode particles. Accordingly, in this study we compare the results of pristine and MWCNT networked cathode systems. Also, to gain further insight into the mechanism responsible for the enhanced performance of the cathode materials, we have investigated these systems using solid state impedance spectroscopy. The scope of the present investigation is further widened with the fabrication of mesocarbon microbeads (MCMB) vs. $\mathrm{LiFePO}_{4} / \mathrm{C}-$ MWCNT and $\mathrm{Li}_{4} \mathrm{Ti}_{5} \mathrm{O}_{12}$ vs. $\mathrm{LiFePO}_{4} / \mathrm{C}-\mathrm{MWCNT}$ Li-ion full cells.

\section{Experimental}

A stoichiometric amount of $\mathrm{FeC}_{2} \mathrm{O}_{4} \cdot 2 \mathrm{H}_{2} \mathrm{O}$ (Alfa Aesar) was dissolved in 1.5 $\mathrm{M} \mathrm{HNO}_{3}$ (Merck). $2 \mathrm{M}$ adipic acid aqueous solution (at $50{ }^{\circ} \mathrm{C}$ ) was added drop by drop to this solution, followed by vigorous stirring for $5 \mathrm{~h}$. Subsequently, $\mathrm{LiNO}_{3}$ was added slowly to the mixture solution, and finally $\mathrm{NH}_{4} \mathrm{H}_{2} \mathrm{PO}_{4}$ was added. This solution was subjected to homogenization with stirring and was allowed to remain at $85{ }^{\circ} \mathrm{C}$ for $6 \mathrm{~h}$, resulting in gel formation, which was dried at $110{ }^{\circ} \mathrm{C}$ for $12 \mathrm{~h}$. Then the dried gel was subjected to decomposition, thermolysis at $400{ }^{\circ} \mathrm{C}$ for $2 \mathrm{~h}$, followed by calcination at $700{ }^{\circ} \mathrm{C}$ for $1 \mathrm{~h}$ in an $\mathrm{Ar}$ atmosphere, leaving a highly fluffy mass as the product, comprising both $\mathrm{LiFePO}_{4}$ and residual carbon. For this reason, we labelled the thermolysis product as $\mathrm{LiFePO}_{4} / \mathrm{C}$. After this, the as-synthesized material was embedded in functionalized 5\% MWCNT (Sisco Research Lab Chemicals: MWCNT type 2, outer diameter: 8$15 \mathrm{~nm}$, length: 10-30 $\mu \mathrm{m}$, assay: 95\%, conductivity: 1-4 $\times$ $10^{2} \mathrm{~S} \mathrm{~cm}^{-1}$ ) in $\mathrm{HNO}_{3}$ through sonication for $2 \mathrm{~h}$ in an ethanol medium. Finally, the resulting $\mathrm{LiFePO}_{4} / \mathrm{C}-\mathrm{MWCNT}$ material was heated at $80{ }^{\circ} \mathrm{C}$ for $5 \mathrm{~h}$. This sol-gel synthesis route is shown schematically in Fig. 1.

The crystal structure of the prepared samples was analyzed by X-ray diffractometry using a Bruker D8 Advance X-ray diffractometer with a $\mathrm{Cu} \mathrm{K} \alpha$ X-ray source $(\lambda=1.5418 \AA)$. Measurements were recorded in the $2 \theta$ range $10-80^{\circ}$, and the XRD data were refined using a least squares data refinement program. The morphology of these particles was examined using a Hitachi $\mathrm{S}-3000 \mathrm{H}$ transmission electron microscope (TEM), and the corresponding selected area electron diffraction patterns (SAED) were also recorded. The amount of residual carbon present in the thermolysis product was analyzed using a CHNOS elemental analyzer (Elementar, Vario EL III) and was found to be around $6.5 \%$. Solid state and electrochemical impedance spectroscopy (EIS) analyses were carried out for both the cathode materials and the fabricated electrochemical cells using a VM3 Multichannel electrochemical workstation over a frequency range of $5 \mathrm{mHz}$ to $1 \mathrm{MHz}$.

All electrochemical characterizations were carried out using a CR-2032 cell configuration. Coin cells (half cells) were assembled using lithium foil (thickness: $0.75 \mathrm{~mm}$ ) as the anode and the synthesized $\mathrm{LiFePO}_{4} / \mathrm{C}$ or $\mathrm{LiFePO}_{4} / \mathrm{C}-\mathrm{MWCNT}$ materials coated on $\mathrm{Al}$ foil as the cathode. In an attempt to examine

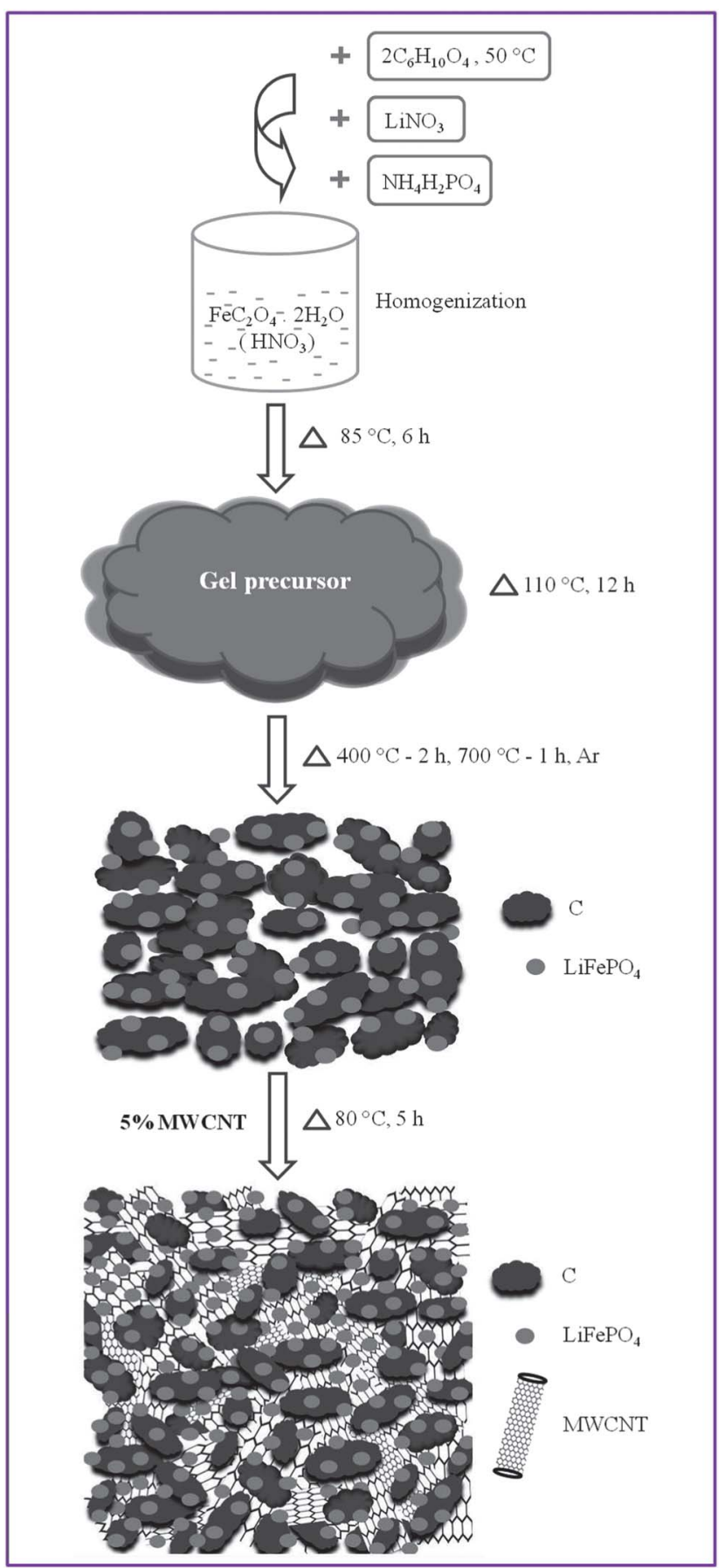

Fig. 1 Scheme of the synthesis of $\mathrm{LiFePO}_{4} / \mathrm{C}$, and networking with MWCNTs.

the complete performance of the synthesized cathode system, the electrochemical study was extended to the fabrication of Li-ion full cells with Celgard ${ }^{\circledR} 2340$ separator using negative electrodes of mesocarbon microbeads (MCMB, commercial sample obtained from Lin Yi DaKe Trade Co. Ltd, Grade: $\mathrm{H}_{1}$ ) or $\mathrm{Li}_{4} \mathrm{Ti}_{5} \mathrm{O}_{12}$, and a positive electrode of $\mathrm{LiFePO}_{4} / \mathrm{C}-\mathrm{MWCNT}$. In this cell design, a $1 \mathrm{M}$ solution of $\mathrm{LiPF}_{6}$ in $1: 1(\mathrm{v} / \mathrm{v})$ ethylene carbonate, dimethyl carbonate (EC-DMC) mixture was used as the electrolyte. For the $\mathrm{Li}$-ion $\mathrm{Li}_{4} \mathrm{Ti}_{5} \mathrm{O}_{12}$ vs. $\mathrm{LiFePO}_{4} / \mathrm{C}-\mathrm{MWCNT}$ full cell studies, $\mathrm{Li}_{4} \mathrm{Ti}_{5} \mathrm{O}_{12}$ nanopowder was synthesized by a 
solution-combustion synthesis using titanyl nitrate $\left[\mathrm{TiO}\left(\mathrm{NO}_{3}\right)_{2}\right]$ and $\mathrm{LiNO}_{3}$ as the oxidant precursors and glycine as the fuel, as in our earlier report. ${ }^{27}$

Furthermore, the anodes were fabricated by doctor bladecoating a slurry comprising $80 \%$ of the material (MCMB, $\mathrm{Li}_{4} \mathrm{Ti}_{5} \mathrm{O}_{12}$ ), $15 \%$ super carbon (SP-carbon, Timcal) and $5 \%$ polyvinylidene fluoride (PVdF) binder in $N$-methyl-2-pyrrolidone (NMP) coated onto copper foil $(9 \mu \mathrm{m})$. The two kinds of cathode slurries prepared in this study had the relative compositions (wt\%) of cathode sample : MWCNT : SP-carbon : PVdF (NMP) in the ratios of $80: 0: 15: 5$ (for pristine $\mathrm{LiFePO}_{4} / \mathrm{C}$ ) and $80: 5: 10: 5$ (for the $\mathrm{LiFePO}_{4} / \mathrm{C}-\mathrm{MWCNT}$ networked cathode). To fabricate the electrodes, these slurries were coated over aluminum foil $(15 \mu \mathrm{m})$ and dried at $85{ }^{\circ} \mathrm{C}$ for $12 \mathrm{~h}$ in a vacuum oven. The area, thickness and weight of the positive electrode were $1.54 \mathrm{~cm}^{2}, 75 \mu \mathrm{m}$ and $12.3 \mathrm{mg}$ (active material, $80 \%$ ), respectively, to obtain two kinds of cells, Li-ion half cells ( $\mathrm{Li} v s$. $\mathrm{LiFePO}_{4} / \mathrm{C}, \mathrm{Li}$ vs. $\mathrm{LiFePO}_{4} / \mathrm{C}-\mathrm{MWCNT}$ ) and Li-ion full cells (MCMB vs. $\mathrm{LiFePO}_{4} / \mathrm{C}-\mathrm{MWCNT}, \mathrm{Li}_{4} \mathrm{Ti}_{5} \mathrm{O}_{12}$ vs. $\quad \mathrm{LiFePO}_{4} / \mathrm{C}-$ MWCNT). In the Li-ion full cells, the negative : positive weight ratios of active material were $\sim 0.5: 1\left(\mathrm{MCMB}^{2} \mathrm{LiFePO}_{4} / \mathrm{C}-\right.$ MWCNT) and $1: 1\left(\mathrm{Li}_{4} \mathrm{Ti}_{5} \mathrm{O}_{12}: \mathrm{LiFePO}_{4} / \mathrm{C}-\mathrm{MWCNT}\right)$. The cells were assembled in an argon-filled glove box (mBRAUN MB200G) with oxygen and moisture levels less than $0.1 \mathrm{ppm}$. Galvanostatic charge-discharge studies were carried out in the voltage range $2.5-4.5 \mathrm{~V}$ and $1.0-2.5 \mathrm{~V}$ at $\mathrm{C} / 10,1 \mathrm{C}, 2 \mathrm{C}, 3 \mathrm{C}$ and $5 \mathrm{C}$ rates at room temperature using an Arbin multichannel cycler instrument (BT2000).

\section{Results and discussion}

\subsection{Structural analysis}

The present synthesis based on sol-gel thermolysis produced well grown, single phase $\mathrm{LiFePO}_{4} / \mathrm{C}$ nanocrystalline particles. The corresponding powder XRD pattern yielded diffraction planes that could be indexed to the orthorhombic space group

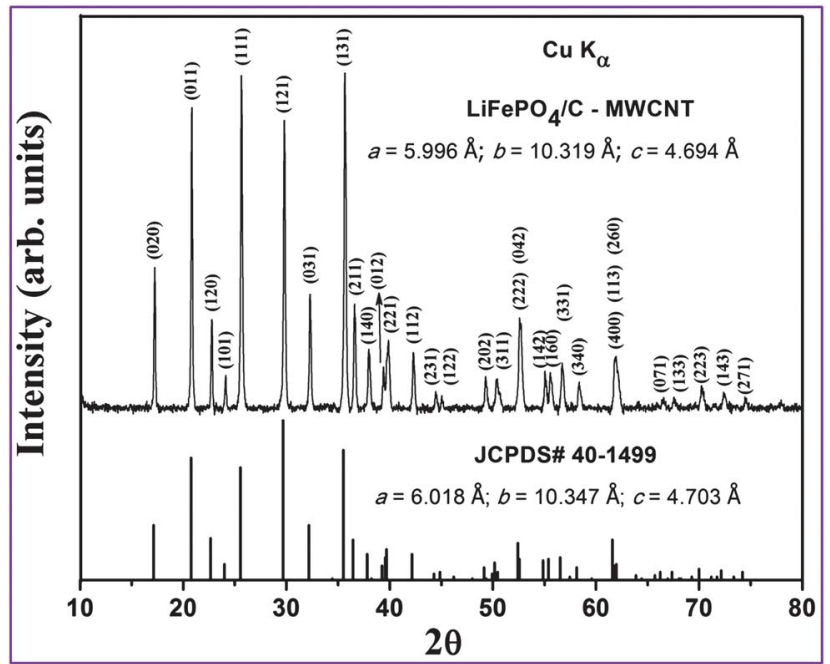

Fig. 2 X-ray diffraction pattern of $\mathrm{LiFePO}_{4} / \mathrm{C}-\mathrm{MWCNT}$ including the refined crystallographic cell parameters $(a, b, c)$, consistent with JCPDS \#40-1499.
Pnma, corresponding to the standard olivine $\mathrm{LiFePO}_{4}$ system, as can be seen from the pattern of JCPDS \#40-1499 in Fig. 2, showing the pattern of $\mathrm{LiFePO}_{4} / \mathrm{C}-\mathrm{MWCNT}$ as a representative example. On closer examination of this XRD pattern, the sharp lines observed suggests the highly crystalline nature of the sample, apart from secondary impurity phase(s). Furthermore, the refined crystallographic unit cell parameter values $a=$ 5.996, $b=10.319$ and $c=4.694 \AA$ A deduced using a simple least squares refinement program (generated by Roy G. Garvey, Department of Chemistry, North Dakota State University, USA), showed good agreement with standard values as shown in Fig. 2.

The particle morphology of the as-synthesized particles shown in the TEM images showed nanoparticles of irregular polyhedral morphology. Although these cathode particles are agglomerated, we can make a reasonable estimate of the average size of the particles from the size information based on individual isolated particles, as marked in Fig. 3(i) and (iii), which is found to be around $20 \mathrm{~nm}$ for both pristine $\mathrm{LiFePO}_{4} / \mathrm{C}$ and $\mathrm{LiFePO}_{4} / \mathrm{C}-\mathrm{MWCNT}$. In the case of former, there are isolated cathode particles lacking face to face contact through carbon particles $(\sim 6.5 \%)$ occurring as a result of the thermolysis reaction. On the other hand, in the latter case, there is an obvious increase in the face to face contact between particles through MWCNT networking. Another salient feature revealed in the SAED patterns of both the pristine and networked nanoparticles (with the incident electron beam along the [111] direction) is the occurrence of diffraction spots resembling parallel lines (Fig. 3(ii) and (iv)). This may suggest some kind of orientation in the faces of the granular $\mathrm{LiFePO}_{4} / \mathrm{C}$ nanoparticles. Hence, it is reasonable that problem of the low

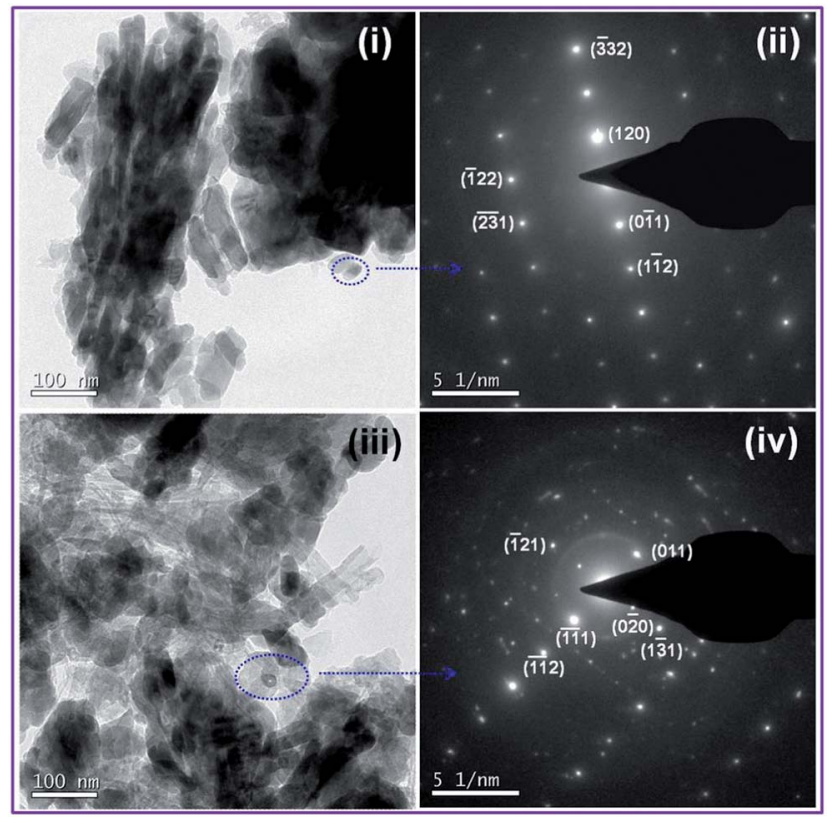

Fig. 3 Nanoparticle morphology observations from TEM images and corresponding SAED patterns for $\mathrm{LiFePO}_{4} / \mathrm{C}$ (panel (i) and (ii)) and $\mathrm{LiFePO}_{4} / \mathrm{C}-\mathrm{MWCNT}$ (panel (iii) and (iv)). 
electronic conductivity of this potential cathode nanomaterial can be mitigated through embedding the cathode nanomaterials in MWCNTs to form a networked frame structure, ${ }^{28}$ as the MWCNTs provide an easy conducting path for electrons. ${ }^{17}$ Eventually this networking with the conducting MWCNTs provides a copious supply of electrons at the electrochemical reaction sites, i.e. the $\mathrm{Fe}^{2+/ 3+}$ sites of the cathode.

\subsection{Insights from solid state electrode and electrochemical cell impedance characteristics}

Motivated by the clear evidence on the role of cathode configuration and its constituents in the enhanced electrochemical performance (as would be seen in the coming sections), solid state impedance studies were focused on the actual electrode used for cell fabrication. Detailed examination of the obtained impedance characteristics can be divided into two sections, the low and high frequency regions. At the high frequency end (0.1$1 \mathrm{MHz}$ ), we observe a precise inductive loop with reverse curvature, identical in both cases (Fig. 4, left sub-panel), which is a clear attribute of inductive impedance. This may stem from the sole ferromagnetic iron (Fe) species with high spin becoming prominent at high frequencies, resulting in an identical pattern for both electrodes. However, at the low frequency end $(1-1000 \mathrm{~Hz})$ there is a substantial difference in the solid state electrode impedance characteristics between the cathodes made using the $\mathrm{LiFePO}_{4} / \mathrm{C}$ and the $\mathrm{LiFePO}_{4} / \mathrm{C}-$ MWCNT systems. From a simple glance at the impedance spectra given in Fig. 4a, a significant three-fold drop in ohmic resistance is observed for the networked system. From Fig. 4a, we find that the diameter of the semicircular impedance profile representing the ohmic resistance of the materials decreases from $2125 \Omega$ for the pristine system to $800 \Omega$ when networked with MWCNT. Obviously, the higher $R$ and $C$ values observed for the pristine $\mathrm{LiFePO}_{4} / \mathrm{C}$ system are the result of the constrained flow of charge due to possible trapping at the numerous defect centers present in the inter- and intra-granular regions of the cathode particles. Furthermore it should be borne in mind that the drop in $R$ value observed for the networked system will result in the minimization of undesirable localized Joule heating of the electrode. In order to explain the simple physical meaning of different components of the fitted impedance equivalent circuits, the emergence of various resistor, $R$, and capacitor, $C$, components can be pictured in terms of the pronounced difficulty for the flow of charge carrier in a given medium and localization, or accumulation of charge at a given point, respectively. The appearance of an inductance, $L$, component in a given equivalent circuit can be attributed to the presence of a magnetic species opposing the change, which is pronounced at high frequencies.

The entire impedance profiles could be reasonably fitted using simple equivalent circuits $\left(\chi^{2}=8.285 \times 10^{-3}\right)$ with $R$ and $C$ parallel Vogit element constituents (Fig. 4a). However, there was significant residue observed only in the profile corresponding to the pristine $\mathrm{LiFePO}_{4} / \mathrm{C}$ electrode remaining unfitted, i.e. the 'fuzzy' region of the impedance curve in the low frequency region (indicated using the shaded arrow in Fig. 4, right sub-panel). This effect observed in earlier reports from other research groups ${ }^{\mathbf{2 9}, 30}$ in spite of the focus on extensive impedance studies of cathodes. These reports also present a fuzzy impedance profile at the low frequency end for the investigated electrodes. A cursory glance at the impedance profile corresponding to the $\mathrm{LiFePO}_{4} / \mathrm{C}$ cathode at the low frequency end suggests that the residue could not be fitted by a simple RC element, which is intriguing. This may suggest additional impedance components; in particular, the presence of non-linear residue is a clear indicator of a capacitor element which may stem from a kind of charge build-up. Accordingly, as depicted in the right sub-panel of Fig. 4, impedance fitting was attempted confined to the fuzzy region. The best fitted value $\left(\chi^{2}=8.488 \times 10^{-4}\right)$ was possible only when using additional impedance components preceded by the "+" sign, namely ${ }^{+} R_{1}=$ $2060 \Omega,{ }^{+} R_{2}=72.02 \Omega,{ }^{+} C_{1}=20.6 \times 10^{-9} \mathrm{~F}$, and ${ }^{+} C_{2}=7.32 \times$ $10^{-6} \mathrm{~F}$, offering high impedance value as given in Table 1(i). Accordingly, it is reasonable to expect that the high resistance observed would decrease the mobility of charge, while the increased capacitance value may be the result of the clear localization of charge. On the other hand, in the case of the $\mathrm{LiFePO}_{4} / \mathrm{C}-\mathrm{MWCNT}$ electrode, there is no such fuzzy impedance profile in the low frequency region, and the profile could be fitted using a simple RC combination (Table 1(ii)) with a good fit $\left(\chi^{2}=3.917 \times 10^{-2}\right)$.

Alternatively this low-frequency fuzzy impedance profile can be seen to have an electronic origin, for the simple reason that when the electrode material is networked with MWCNT, a well established facilitator of electronic conductivity, this phenomenon disappears. That is, the electronic contribution which otherwise appears as charge build-up finds an easy path for relaxation rather than becoming trapped at the inter- and intragrain boundary regions of the granular electrode material (Fig. 4b). The charge mobility may be further enhanced in an electrode system made of nanograins/crystallites showing specific directionality, as the propensity to form a charge gradient is minimal in this scenario. From the fitted impedance parameters (Table 1 and Fig. 4a) for the entire frequency region and the logistics generated from them, we observe that there are numerous capacitor elements, of which the one with label $C_{2}$ indicates a several orders of magnitude higher charge storage ability, in addition to these capacitors acting as traps for the free flowing charge to achieve high electrochemical capacity. Networking the electrode material with MWCNT may help to overcome this bottleneck for the unhindered flow of charge. Furthermore the negative impedance components $L_{1}=-0.98 \times$ $10^{-6} \mathrm{H}$ and $C_{4}=-5.28 \times 10^{-9}$ (Table 1 (ii)) can be rationalized as the reversal of the charge flow direction/spin component. Furthermore, it is imperative to explain the origin of the capacitor elements acting as charge reservoirs or traps. The interfacial regions of the granules of the electrode act as a space charge layer, apart from the less conductive grain-core and the interior regions coupled with other electrostatic parameters, as can be visualized through the relation. ${ }^{31}$

$$
\lambda=\sqrt{\kappa \varepsilon_{0}} R T / 2 C_{\infty} Z^{2} F^{2}
$$




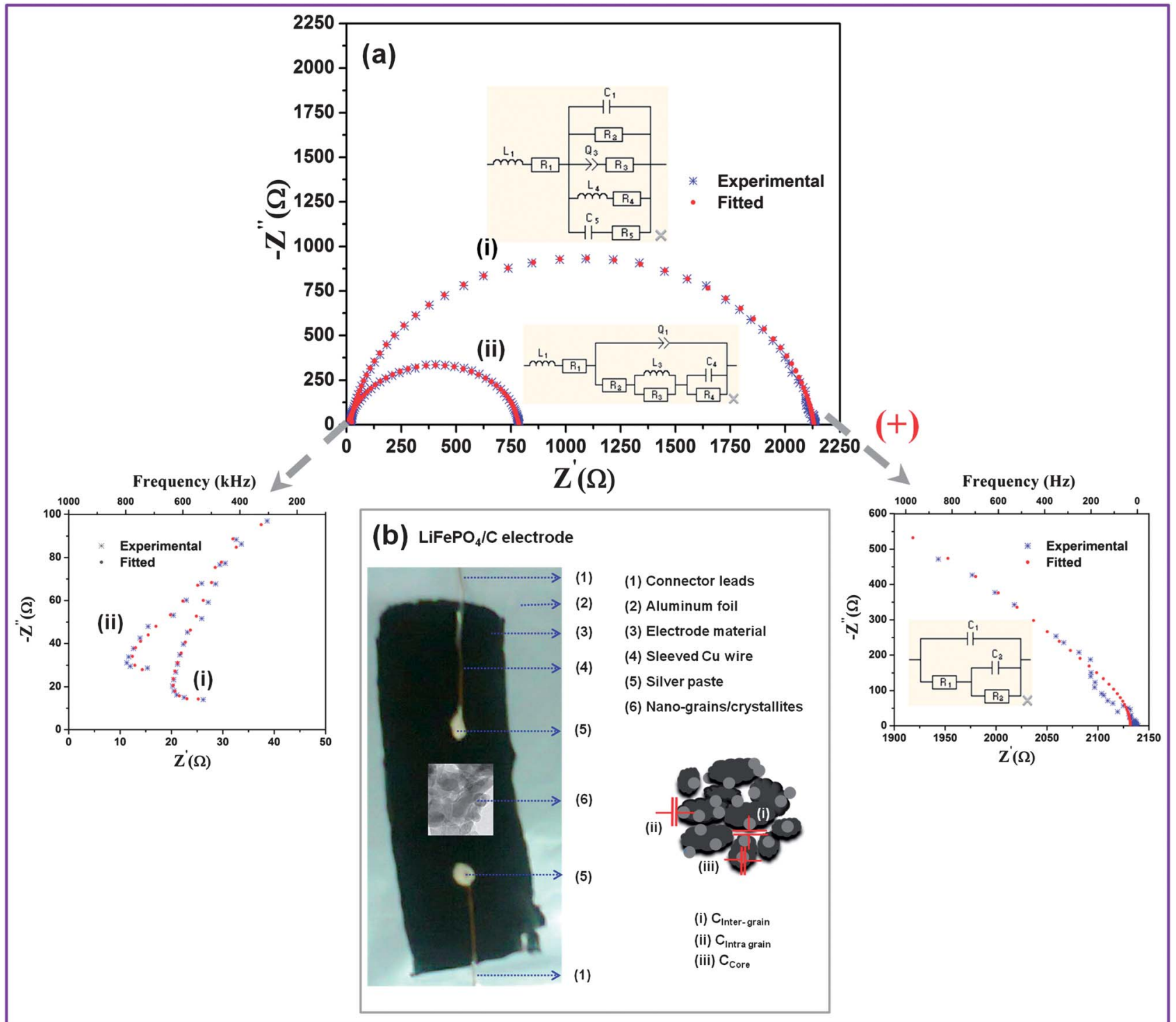

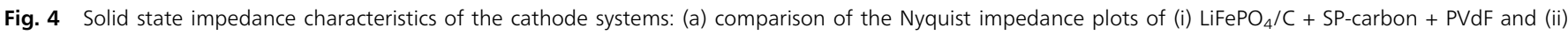

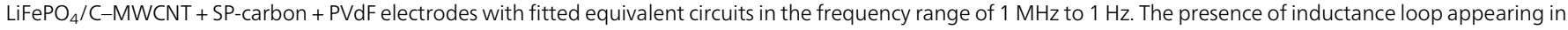

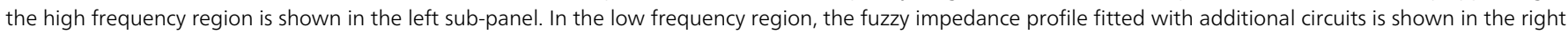

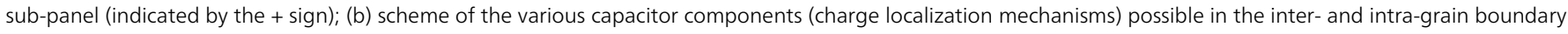
regions of the $\mathrm{LiFePO}_{4} / \mathrm{C}$ electrode.

where $\kappa$ is the dielectric constant of the medium, $Z$ is the number of charges on the defect, $C_{\infty}$ is the molar concentration of the defect far from the interface and $\varepsilon_{0}, R, T$ and $F$ are constants. This report gives clear experimental evidence of the localization of charge, resulting in low capacity versus high capacity through the enhanced mobility of charge, which may open up newer possibilities in the design of cathodes for Li-ion batteries.

Furthermore, to understand the mechanisms responsible for the capacity enhancement, electrochemical impedance spectra (EIS) of the cells were also recorded for the cells fabricated with both types of cathode systems, as indicated in Fig. 5 in the complex plane impedance Nyquist plot. EIS data are more informative than ohmic resistance $(R)$ based conductivity data, because the EIS data can reveal information on the movement and localization of charge carriers, their frequency dependence and relationship with other impedance components, namely capacitance $(C)$ and inductance $(L)$. Upon close scrutiny of the plot, there is an obvious increase in linear conductivity, with a $\sim 30 \%$ decrease in ohmic resistance coupled with a pronounced decrease in capacitance, which is revealed by the depressed semicircle with $\sim 50 \%$ drop in the $y$-axis value for the $\mathrm{LiFePO}_{4} /$ C-MWCNT cells. The drop in capacitance observed is a clear indicator of the delocalization of charge owing to the easy conducting path for the free flow of charge. The drop in the electrode-electrolyte charge transfer resistance $\left(R_{\mathrm{ct}}\right)$ suggests a significant increase in conductivity, which can be rationalized by the enhanced conductivity of the electrode when networked 
Table 1 Solid state impedance (fitted) characteristics of LiFePO $4 / C+$ SP-carbon + PVdF vs. LiFePO $4 / C-M W C N T+$ SP-carbon + PVdF cathode systems ${ }^{a}$

\begin{tabular}{|c|c|c|c|c|}
\hline $\begin{array}{l}\text { Sample } \\
\text { no. }\end{array}$ & Electrode system & $\begin{array}{l}\text { Impedance components: } L \\
(\mathrm{H}), C(\mathrm{~F}), R(\Omega)\end{array}$ & Phase element $(\Phi)$ & Remarks \\
\hline (i) & $\begin{array}{l}\mathrm{LiFePO}_{4} / \mathrm{C}+\text { SP-carbon }+ \\
\mathrm{PVdF}\end{array}$ & $\begin{array}{l}L_{1}=17.28 \times 10^{-6}, L_{4}=208 \\
\times 10^{-6}, C_{1}=31.29 \times 10^{-12}, \\
C_{5}=9.5 \times 10^{-12}, R_{1}=-945, \\
R_{2}=10.2 \times 10^{6}, R_{3}=14.07 \\
\times 10^{2}, R_{4}=30.79 \times 10^{2}, R_{5}= \\
13.876 \times 10^{3},{ }^{+} C_{1}=20.6 \times \\
10^{-9},{ }^{+} C_{2}=7.32 \times 10^{-6}, \\
{ }^{+} R_{1}=2060,{ }^{+} R_{2}=72.02\end{array}$ & $Q_{3}=20.91 \times 10^{-9}, a_{3}=0.92$ & $\begin{array}{l}\text { Several capacitor elements - } \\
\text { multiple localization of } \\
\text { charge; } 3 \text {-fold increase in } \\
\text { capacitance, }{ }^{+} C_{2} \text { pronounced } \\
\text { charge build-up, high ohmic } \\
\text { resistance - restricted charge } \\
\text { flow. }\end{array}$ \\
\hline (ii) & $\begin{array}{l}\mathrm{LiFePO}_{4} / \mathrm{C}-\mathrm{MWCNT}+\mathrm{SP}- \\
\text { carbon }+\mathrm{PVdF}\end{array}$ & $\begin{array}{l}L_{1}=-0.98 \times 10^{-6}, L_{3}=1.36 \\
\times 10^{-3}, C_{4}=-5.28 \times 10^{-9} \\
R_{1}=6.24, R_{2}=590.5 \\
R_{3}=21.07, R_{4}=189.8\end{array}$ & $Q_{1}=95.51 \times 10^{-9}, a_{1}=0.89$ & $\begin{array}{l}\text { Low ohmic resistance - } \\
\text { facilitates charge flow; single } \\
\text { capacitor with low negative } \\
\text { value, free flow of charge/ } \\
\text { release. }\end{array}$ \\
\hline
\end{tabular}

${ }^{a}$ SP-carbon: super carbon, PVdF: polyvinylidene fluoride.

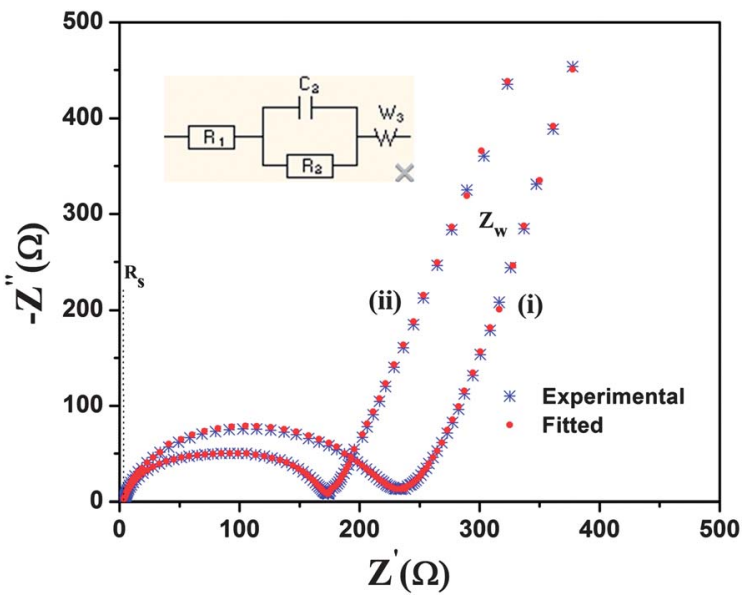

Fig. 5 Electrochemical impedance spectra of (i) Li vs. LiFePO 4 /C and (ii) Li vs. $\mathrm{LiFePO}_{4} / \mathrm{C}-\mathrm{MWCNT}$ cells with the fitted equivalent circuit in the frequency range of $100 \mathrm{kHz}$ to $5 \mathrm{mHz}$ (1 M LiPF 6 in 1:1 EC-DMC solvents).

with MWCNT, while the decrease in electrostatic capacitance is more intriguing, that is, the decreased localization of electrostatic charge in the networked electrode material as a result of the increased charge mobility in the presence of easy conducting pathways, which could result in the electrochemical capacity enhancement as observed. Apart from these electrochemical impedance components, it can be seen that the high frequency end the electrolyte offers a solution resistance $\left(R_{\mathrm{S}}\right)$, while at the low frequency end the observed slanted line profile can be attributed to the diffusion of $\mathrm{Li}^{+}$ions through a Warburg process $\left(Z_{\mathrm{w}}\right)$. Summing up the results, the electrochemical capacity enhancement can be solely attributed to the different cathodes in the two cases, rather than from the other identical constituents.

\subsection{Electrochemical performance of Li-ion half cells}

For eventual application of any electrochemical materials synthesized, charge-discharge studies hold the key to determining their feasibility. With this objective in mind, charge-discharge studies have been carried out for the Li-ion cells. Using the charge-discharge voltage profile study, it is possible to infer a flat cell voltage of $3.4 \mathrm{~V}$ for the $\mathrm{LiFePO}_{4} / \mathrm{C}-$ MWCNT at a $\mathrm{C} / 10$ rate after 50 cycles (Fig. 6). These results indicate that the synthesized sample exhibits superior target phase formation, in agreement with the structural parameters deduced by XRD. It is pertinent to highlight here the importance of correlating particle size versus phase separation in the $\mathrm{LiFePO}_{4}$ system, to eventually determine the electrochemical performance. ${ }^{32-34}$ Ichitsubo et al. have recently demonstrated that smaller particles $(<10 \mathrm{~nm})$ exhibit a single phase reaction, while larger particles $(10-30 \mathrm{~nm})$ exhibit phase separation to $\mathrm{LiFePO}_{4}$ and $\mathrm{FePO}_{4}$ phases, indicated by the prominent cell voltage plateau in the voltage $v s$. capacity profile. ${ }^{32}$ Hence it is reasonable that the cathode particles in the present study with sizes around $20 \mathrm{~nm}$ exhibiting a cell plateau region also show a phase separated regime.

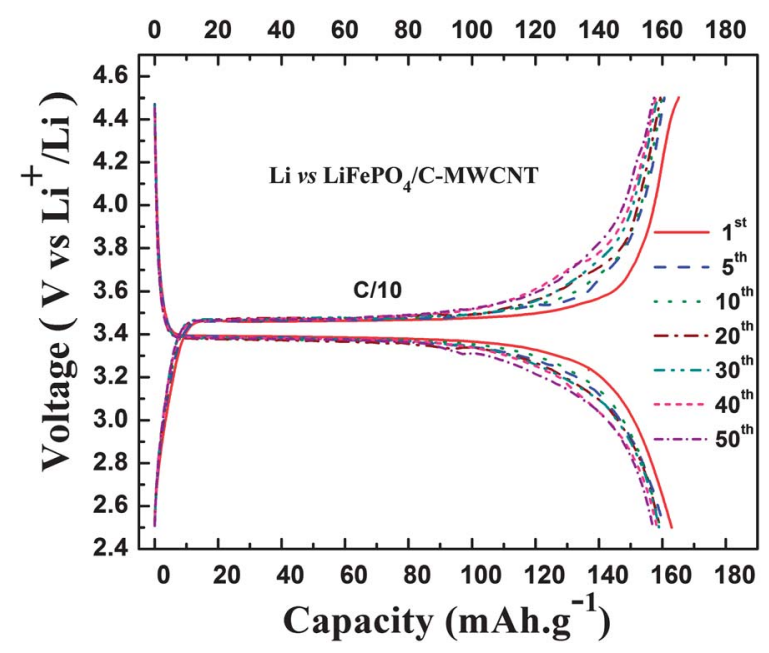

Fig. 6 Voltage vs. capacity profiles of a Li vs. LiFePO $/$ /C-MWCNT cell at C/10. 
More importantly, the $\mathrm{LiFePO}_{4} / \mathrm{C}-\mathrm{MWCNT}$ electrode delivered an initial discharge capacity of $163 \mathrm{~mA} \mathrm{~h} \mathrm{~g}{ }^{-1}$ with an irreversible capacity loss of $2 \mathrm{~mA}$ during the $1^{\text {st }}$ cycle. The charge-discharge capacities at the $50^{\text {th }}$ cycle remained at the same value of $157 \mathrm{~mA} \mathrm{~h} \mathrm{~g}^{-1}$, thereby confirming the complete Coulombic efficiency of this unique electrochemical system. The capacity retention at the $50^{\text {th }}$ cycle is about $96 \%$. Inspection of Fig. 7 and 8 suggests a pronounced increase in capacity with good retention for the cell employing $\mathrm{LiFePO}_{4} / \mathrm{C}-\mathrm{MWCNT}$ (yielding 163 and $145 \mathrm{~mA} \mathrm{~h} \mathrm{~g}^{-1}$ capacity) as compared to the lower capacity (125 and $92 \mathrm{~mA} \mathrm{~h} \mathrm{~g}{ }^{-1}$ ) observed with the pristine system at different rates $\left(\mathrm{C} / 10\right.$ and $1 \mathrm{C}$ for the $1^{\text {st }}$ cycle). In view of the impressive rate capability results of the $\mathrm{LiFePO}_{4} / \mathrm{C}-$ MWCNT cathode system, investigations were further extended to $2 \mathrm{C}\left(135 \mathrm{~mA} \mathrm{~h} \mathrm{~g}^{-1}\right), 3 \mathrm{C}\left(121 \mathrm{~mA} \mathrm{~h} \mathrm{~g}^{-1}\right)$ and $5 \mathrm{C}\left(103 \mathrm{~mA} \mathrm{~h} \mathrm{~g}^{-1}\right)$, at which the system showed remarkable stability after 50 cycles. The decrease in capacity at higher C-rate can be rationalized in terms of limitations stemming from the poor electronic and ionic conductivities of this $\mathrm{LiFePO}_{4} / \mathrm{C}-\mathrm{MWCNT}$ system, impeding the free flow of charge.

\subsection{Features and performance of Li-ion full cells}

The application potential of the networked cathode materials encompasses a range of cell voltages, safety issues and so on. In terms of cell voltage, $\mathrm{MCMB} v s$. $\mathrm{LiFePO}_{4} / \mathrm{C}-\mathrm{MWCNT}$ offers a cell voltage of $\sim 3 \mathrm{~V}$, while the $\mathrm{Li}_{4} \mathrm{Ti}_{5} \mathrm{O}_{12}$ vs. $\mathrm{LiFePO}_{4} / \mathrm{C}-\mathrm{MWCNT}$ couple provides a voltage of about $\sim 2 \mathrm{~V}$, so the scope for the application of these systems is broad. Bearing these important issues in mind, two kinds of Li-ion full cells, using MCMB and $\mathrm{Li}_{4} \mathrm{Ti}_{5} \mathrm{O}_{12}$ as anodes, have been fabricated as discussed below. Electrochemical studies of the Li-ion full cells, MCMB vs. $\mathrm{LiFePO}_{4} / \mathrm{C}-\mathrm{MWCNT}$ and $\mathrm{Li}_{4} \mathrm{Ti}_{5} \mathrm{O}_{12}$ vs. $\mathrm{LiFePO}_{4} / \mathrm{C}-\mathrm{MWCNT}$, made in our lab exhibited open circuit voltages of 0.2 and $0.37 \mathrm{~V}$ respectively for these systems. After an aging period of $24 \mathrm{~h}$, these cells were used for further electrochemical studies. In order to evaluate the electrochemical performance of the first kind of Li-ion full cell (MCMB vs. $\mathrm{LiFePO}_{4} / \mathrm{C}-\mathrm{MWCNT}$ ), it is essential to pass through a formation cycle process at a low

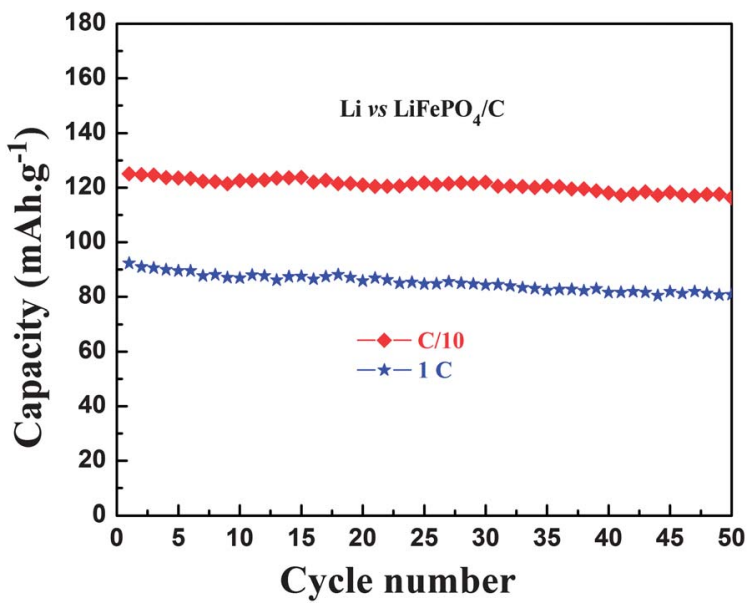

Fig. 7 Capacity vs. cycle performance of the $\mathrm{Li}$ vs. $\mathrm{LiFePO}_{4} / \mathrm{C}$ cell at different rates: $\mathrm{C} / 10$ and $1 \mathrm{C}$ in the voltage range from 2.5 to $4.5 \mathrm{~V}$.

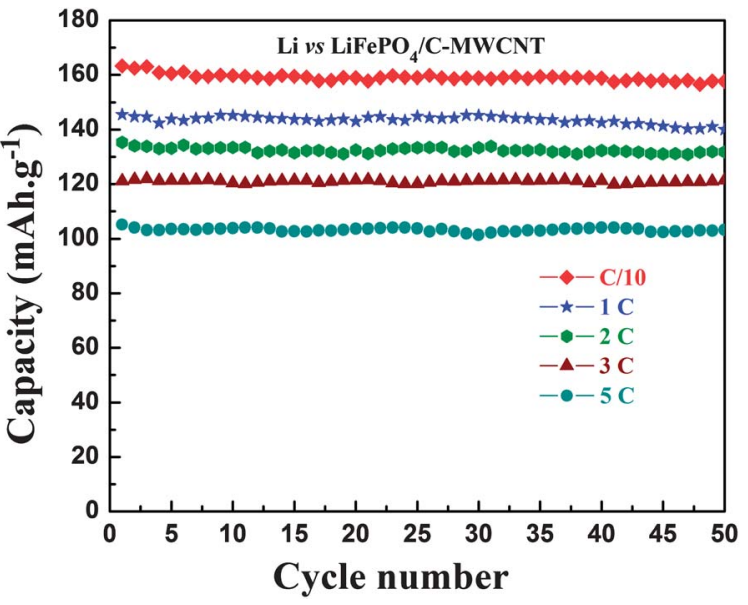

Fig. 8 Capacity vs. cycle performance of the Li vs. LiFePO $4 / C-M W C N T$ cell at different rates: C/10, 1 C, 2 C, 3 C and 5 C in the voltage range from 2.5 to $4.5 \mathrm{~V}$.

current rate of $\mathrm{C} / 25$ for the $1^{\text {st }}$ cycle in constant current mode. The formation cycle is essential for stabilization of the active materials through solid electrolyte interface (SEI) film formation in the cell. ${ }^{35,36}$ The SEI film has the intrinsic advantage of preventing further chemical reaction between the electrolyte and the active materials. The life and discharge performance of the Li-ion full cell are highly dependent on the SEI formed over the carbon electrode (MCMB) during the formation process. Hence, it is expected that the applied low current can produce a denser SEI layer, which is advantageous for improving the cyclability of the Li-ion full cell. The cell voltage $v s$. cell capacity performance of the Li-ion full cell (MCMB vs. $\mathrm{LiFePO}_{4} / \mathrm{C}-$ MWCNT) is shown in Fig. 9. There is a pronounced slope in the cell voltage of cell due to the MCMB anode, which may lead to a drop in capacity over several cycles.

On the other hand, in the case of the $\mathrm{Li}_{4} \mathrm{Ti}_{5} \mathrm{O}_{12}$ vs. $\mathrm{LiFePO}_{4} /$ C-MWCNT full cell, after $24 \mathrm{~h}$ aging the charge-discharge studies can be carried out directly as there is no SEI film formation. ${ }^{37}$ The cell voltage $v s$. cell capacity performance of the

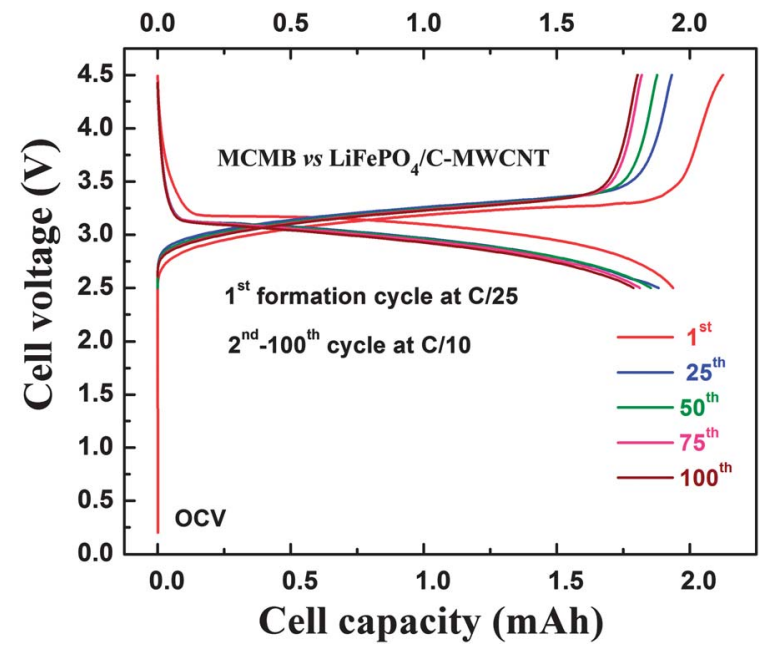

Fig. 9 Cell voltage vs. capacity performance of the MCMB vs. LiFePO $/ \mathrm{C}_{-}$ MWCNT Li-ion full cell in the voltage range from 2.5 to $4.5 \mathrm{~V}$ at C/10. 


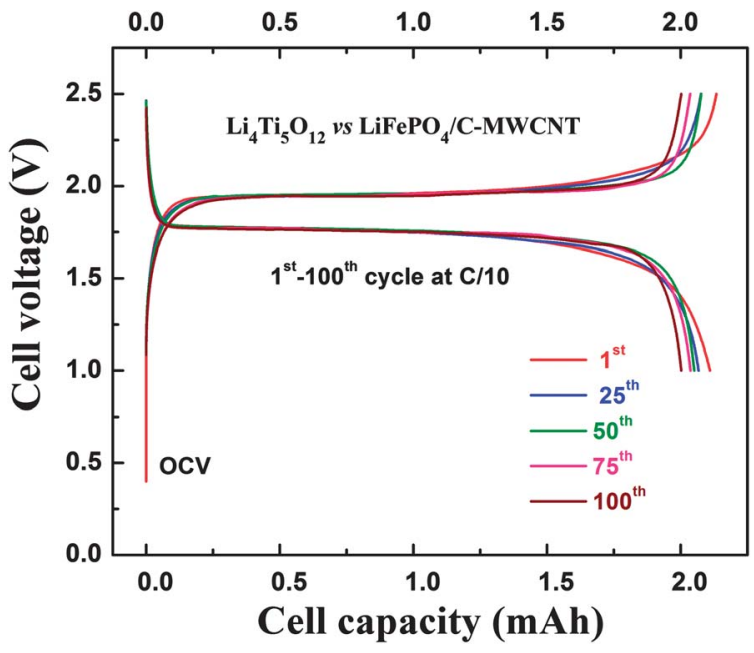

Fig. 10 Cell voltage vs. capacity performance of the $\mathrm{Li}_{4} \mathrm{Ti}_{5} \mathrm{O}_{12}$ vs. $\mathrm{LiFePO}_{4} / \mathrm{C}-$ MWCNT Li-ion full cell in the voltage range from 1.0 to $2.5 \mathrm{~V}$ at $\mathrm{C} / 10$.

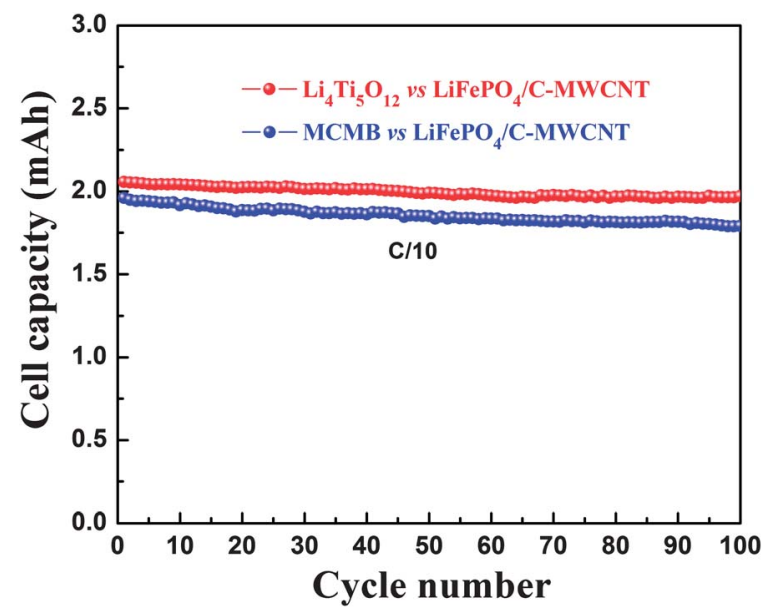

Fig. 11 Cell capacity vs. cycle performance of the MCMB vs. LiFePO ${ }_{4} / \mathrm{C}-\mathrm{MWCNT}$ and $\mathrm{Li}_{4} \mathrm{Ti}_{5} \mathrm{O}_{12}$ vs. $\mathrm{LiFePO}_{4} / \mathrm{C}-\mathrm{MWCNT}$ Li-ion cells in the voltage range $2.5-4.5 \mathrm{~V}$, $1.0-2.5 \mathrm{~V}$, up to 100 cycles at $\mathrm{C} / 10$.

Li-ion full cell $\left(\mathrm{Li}_{4} \mathrm{Ti}_{5} \mathrm{O}_{12}\right.$ vs. $\left.\mathrm{LiFePO}_{4} / \mathrm{C}-\mathrm{MWCNT}\right)$ is shown in Fig. 10. Obviously, in this system the discharge voltage profile at $1.85 \mathrm{~V}$ is reasonably flat over several cycles, suggesting the remarkable cycling stability of the second kind of full cell. Comparing the consolidated cell performance of these two kinds of full cells (Fig. 11), the MCMB carbon-based full cell appears to be marginally inferior ( $\sim 8 \%$ lower capacity) to the $\mathrm{Li}_{4} \mathrm{Ti}_{5} \mathrm{O}_{12}$-based full cell in terms of cell capacity. These Li-ion full cells (MCMB carbon and $\mathrm{Li}_{4} \mathrm{Ti}_{5} \mathrm{O}_{12}$ ) delivered discharge capacities of 1.94 and $2.1 \mathrm{~mA} \mathrm{~h}\left(1^{\text {st }}\right.$ cycle) and 1.78 and $2.0 \mathrm{~mA} \mathrm{~h}$ $\left(100^{\text {th }}\right.$ cycle), respectively. Owing to the impressive capacity retention, cycling studies were limited to 100 cycles.

\section{Conclusions}

Small particles of olivine $\mathrm{LiFePO}_{4} / \mathrm{C}$ of around $20 \mathrm{~nm}$ in size have been synthesized employing sol-gel route and using adipic acid as a chelating agent. To achieve high electrochemical capacity for use in Li-ion batteries, the as-synthesized cathode materials were networked with MWCNTs. The study based on the solid state impedance characteristics of the olivine $\mathrm{LiFePO}_{4} /$ C cathode illustrated the importance of a highly electronic conducting path, realized through the networking of the cathode material with MWCNTs. In the absence of an efficient conducting path the charge is localized/trapped at the interand intra-grain boundaries and the core regions of the cathode particles, eventually resulting in low capacity. Also, the study based on the complete electrode systems may be helpful for optimizing the cell performances of electrode materials. For reasons of completeness encompassing safety, cell voltage etc., the thus-synthesized networked cathode materials have been used in the fabrication of MCMB vs. $\mathrm{LiFePO}_{4} / \mathrm{C}-\mathrm{MWCNT}$ and $\mathrm{Li}_{4} \mathrm{Ti}_{5} \mathrm{O}_{12}$ vs. $\mathrm{LiFePO}_{4} / \mathrm{C}-\mathrm{MWCNT}$ full cells, and exhibited discharge capacities of 1.94 and $2.1 \mathrm{~mA} \mathrm{~h}$, respectively.

\section{Acknowledgements}

P. Manikandan acknowledges the Council of Scientific and Industrial Research (CSIR), New Delhi for granting financial support for the above work in the form of a senior research fellowship. The authors also wish to thank the Director of CSIRCECRI for the support.

\section{References}

1 A. K. Pathi, K. S. Nanjundaswamy and J. B. Goodenough, J. Electrochem. Soc., 1997, 144, 1188-1194.

2 A. K. Pathi, K. S. Nanjundaswamy and J. B. Goodenough, J. Electrochem. Soc., 1997, 144, 1609-1613.

3 Q. Huang, M. Yan and Z. Jiang, J. Power Sources, 2006, 156, 541-546.

4 C. Delacourt, L. Laffont, R. Bouchet, C. Wurm, J. B. Leriche, M. Morcette, J. M. Tarascon and C. J. Masquelier, J. Electrochem. Soc., 2005, 152, A913-A921.

5 M. Yonemura, A. Yamada, Y. Takei, N. Sonoyama and R. Kanno, J. Electrochem. Soc., 2004, 151, A1352-A1356.

6 R. Amin, P. Balaya and J. Maier, Electrochem. Solid-State Lett., 2007, 10, A13-A16.

7 R. Amin, C. T. Lin and J. Maier, Phys. Chem. Chem. Phys., 2008, 10, 3519-3523.

8 R. Dominko, M. Bele, M. Gaberscek, M. Remskar, D. Hanzel and J. Jamnik, J. Electrochem. Soc., 2005, 152, A858-A863.

9 Y. Wang, Y. Wang, E. Hosono, K. Wang and H. Zhou, Angew. Chem., Int. Ed., 2008, 47, 7461-7465.

10 S. Y. Chung, J. T. Bloking and Y. M. Chiang, Nat. Mater., 2002, 1, 123-128.

11 I. Bilecka, A. Hintennach, M. D. Rossell, D. Xie, P. Novak and M. Niederberger, J. Mater. Chem., 2011, 21, 5881-5890.

12 A. Yamada, S. C. Chung and K. Hinokuma, J. Electrochem. Soc., 2001, 148, A224-A229.

13 S. F. Yang, P. Y. Zavalij and M. S. Whittingham, Electrochem. Commun., 2001, 3, 505-508.

14 S. F. Yang, Y. N. Song, P. Y. Zavalij and M. S. Whittingham, Electrochem. Commun., 2002, 4, 239-244.

15 J. Wang and X. Sun, Energy Environ. Sci., 2012, 5, 5163-5185. 
16 M. Gaberscek, R. Dominko and J. Jamnik, Electrochem. Commun., 2007, 9, 2778-2783.

17 D. H. Kim and J. Kim, Electrochem. Solid-State Lett., 2006, 9, A439-A442.

18 C. H. Yong, Z. H. Li, Z. Wei, Z. J. Li and L. Q. Feng, Trans. Nonferrous Met. Soc. China, 2010, 20, 614-618.

19 S. B. Lee, S. H. Cho, S. J. Cho, G. J. Park and Y. S. Lee, Electrochem. Commun., 2008, 10, 1219-1221.

20 A. Vajpayee, V. P. S. Awana, G. L. Bhalla, P. A. Bhobe, A. K. Nigam and H. Kishan, Supercond. Sci. Technol., 2009, 22, 15016.

21 G. T. K. Fey, J. G. Chen, Z. F. Wang, H. Z. Yang and T. Prem Kumar, Mater. Chem. Phys., 2004, 87, 246-255.

22 B. Jin, E. M. Jin, K. H. Park and H. B. Gu, Electrochem. Commun., 2008, 10, 1537-1540.

23 J. Yang, J. Wang, Y. Tang, D. Wang, B. Xiao, X. Li, R. Li, G. Liang, T. K. Sham and X. Sun, J. Mater. Chem. A, 2013, 1, 7306-7311.

24 J. Yang, J. Wang, X. Li, D. Wang, J. Liu, G. Liang, M. Gauthier, Y. Li, D. Geng, R. Li and X. Sun, J. Mater. Chem., 2012, 22, 7537-7543.

25 Y. Ding, Y. Jiang, F. Xu, J. Yin, H. Ren, Q. Zhuo, Z. Long and P. Zhang, Electrochem. Commun., 2010, 12, 10-13.
26 B. Marinho, M. Ghislandi, E. Tkalya, C. E. Koning and G. D. With, Powder Technol., 2012, 221, 351-358.

27 A. S. Prakash, P. Manikandan, K. Ramesha, M. Sathiya, J. M. Tarascon and A. K. Shukla, Chem. Mater., 2010, 22, 2857-2863.

28 T. Muraliganth, A. V. Murugan and A. Manthiram, J. Mater. Chem., 2008, 18, 5661-5668.

29 J. J. Biendicho and A. R. West, Solid State Ionics, 2012, 226, 41-52.

30 C. Wang and J. Hong, J. Electrochem. Soc., 2007, 10, A65-A69. 31 J. Maier, Ber. Bunsen-Ges. Phys. Chem., 1986, 90, 26-33.

32 T. Ichitsubo, T. Doi, K. Tokuda, E. Matsubara, T. Kida, T. Kawaguchi, S. Yagi, S. Okada and J. Yamaki, J. Mater. Chem. A, 2013, DOI: 10.1039/c3ta13122j.

33 T. Ichitsubo, K. Tokuda, S. Yagi, M. Kawamori, T. Kawaguchi, T. Doi, M. Oishi and E. Matsubara, J. Mater. Chem. A, 2013, 1, 2567-2577.

34 R. Malik, A. Abdellahi and G. Ceder, J. Electrochem. Soc., 2013, 160, A3179-A3197.

35 S. S. Zhang, J. Power Sources, 2006, 161, 1385-1391.

36 H. H. Lee, Y. Y. Wang, C. C. Wan, M. H. Yang, H. C. Wu and D. T. Shieh, J. Power Sources, 2004, 134, 118-123.

37 A. S. Aric, P. Bruce, B. Scrosati, J. M. Tarascon and W. V. Schalkwijk, Nat. Mater., 2005, 4, 366. 